\title{
Financial Inclusion Index: A Customized Regional Model with Reference to Economically Most Backward Districts of Tamil Nadu, India
}

\author{
M. Sriram \\ Research Scholar, Commerce, School of Social Sciences and Languages, VIT University \\ Vellore 632 014, Tamil Nadu, India; Email: sriram89.m@gmail.com \\ N. Sundaram \\ Professor of Commerce, School of Social Sciences and Languages, VIT University \\ Vellore 632 014, Tamil Nadu, INDIA; Email: nsundaram@vit.ac.in
}

Doi:10.5901/mjss.2015.v6n6p209

Abstract

This paper investigates the extent of financial inclusion in the economically most backward districts of Tamil Nadu, India which consists of four districts namely Cuddalore, Nagapattinam, Tiruvannamalai and Villupuram. This study used customized financial inclusion index to compute the level of financial inclusion for which, the sample size was 384. Optimum allocation stratified random sampling method was used under probability sampling to collect the data through questionnaire. This study resulted with low and below average financial inclusion scores for three districts and above average score for one district. There is no district in the study area found with high level of financial inclusion. The reasons were lack of income, financial illiteracy, complexity in documentation and lack of help desk to guide the needy people. It is the duty of the concerned authorities to scrutinize the status of financial inclusion reach and the people should get involved in the process to lead the financially excluded into access of financial products and services at affordable cost, time and distance.

Keywords: financial inclusion, index, access, availability, usage.

\section{Introduction}

Financial inclusion is a notable factor in the economy for human advancement in association with comprehensive financial development. The framework of financial inclusion advances the people to effectively allot the earnings and spending in optimal and beneficial way. The formal way to connect the financial system with each individual of an economy is possible through access to financial services by the way of institutions like banks, post offices and insurance companies. The availability of required financial services to individuals has significant impact on enhancing the daily administration of monetary related issues. It has a tendency to control the development of informal and unscrupulous finance lenders, who exploit the savers and borrowers by furnishing ambiguous information, lending money with higher rate of interest and lack of transparency.

Researchers and policy makers concur that, in developing countries, a common crisis is the lack of access to formal financial services, lack of credit requirements at affordable cost and lack of lending requirements, which restricts the people from formal financial access. The impossibility to access isolates people in rural and remote regions which create income inequality in the economy (Conroy, 2008). The developing countries realized the importance of an inclusive financial system and have implemented policies to promote financial inclusion. Such policies are opening of no frills account, provision of insurance with endurable premium and affordable credit. It has been recognized as a means to integrate every citizen in the economy and contribute towards the progress of the nation.

Financial inclusion purports the drawing of unbanked population into formal financial system, which is away from financial system access. It provides the unbanked population an opportunity to financial service access that ranges from savings, credit transfers, payments and insurance (Hanning \& Janson, 2010). The financial inclusion process implies its reach by means of easy access along with availability and usage, which are availed by all the people of the economy. To bring the unbanked population into financial access, the possible factors should be measured and monitored in the study area by means of index.

The significance of this paper is to measure the level of financial inclusion in the study area. It is possible by constructing a financial inclusion measurement index, which will support the policy makers and stake holders to make 
financial decisions for savings, investments and spending. This paper measures and analyzes the level of financial inclusion through the index developed by Sarma (2012).

\section{Statement of the Problem}

The universal fact known is two billion of the adult population in the world does not have financial access in formal financial institutions like banks, post offices and insurance companies. Half of this unbanked population is found in India, stated by the World Bank in its report for the year 2014. The average earnings of Indian citizen fall under the category of $\$ 1,046$ and $\$ 4,125$. It is considerably very low when compared to economies with upper middle income and upper income. People of low middle income economy do not have income to save, invest and meet their emergency expense. They earn and spend to fulfill their basic needs. Financial inclusion helps the government and authorities concerned for financial affairs to identify the people who do not hold an account for financial transaction. And make them to access the financial system through policies implemented such as opening of zero balance accounts, credit at affordable cost, insurance with reasonable premium and maturity and advice for optimal financial investment.

\section{Review of Literature}

Social inclusion is the key objective for economic development which includes financial inclusion as an important policy to be fulfilled by developing nations. Initially there were no literatures on how to measure the extent of financial inclusion, which has started to develop in the recent years. The Measure of financial inclusion depends on the way it is defined; it is customized as per the requirement with regards to people, place and income (Kunt \& Klapper, 2012). Some studies have measured financial inclusion by the proportion of population with access to financial services especially the people having a bank account. It is not viable to collect the data from number of bank accounts opened in a particular region because it can only be obtained through nation-wide surveys, besides it is difficult to conduct studies based on survey data.

It is not so easy to measure the financial inclusion because of its inadequate evidence and the use of financial services by households and firms are found to be limited (Claessens, 2006). Despite of several limitations, an econometric approach was used by Honohan (2008) to estimate the access of banking services among households of many countries on basis of survey. Research studies disclose that considering the proportion of population with bank accounts is a single factor to measure financial inclusion and there are many other factors to be considered for measurement. Even the people with bank account were unable to access financial services adequately because of physical and psychological factors as well. Beck et al. (2006) mentioned the term financial inclusion as the access and use of banking services by households and firms. Whereas in some regions, households do not use banking services due to high transaction cost, complex procedures and outreach. In case of firms, there face the difficulty of high opportunity costs. Financial exclusion is the extreme end of financial inclusion, where there is no point of access to any financial services due to geographical, socio-economic and financial access limitations (Anderloni \& Carluccio, 2007).

Various indicators have been used by the researchers in their literature to measure financial inclusion such as number of individual access to bank accounts and number of branches per thousand square kilometer. Indicators like loan and income are also considered to affirm a region as financially included (Beck et al., 2009). The proportion of loan and income at present is above two in rich countries and above eight in poor countries. Peachy \& Roe (2006) stated that an economy can be considered that it has attained complete financial access, if the deposit-Gross Domestic Product ratio is $100 \%$ and the cash-deposit ratio is below $20 \%$. The accessibility of financial services is possible through transaction in bank branches and branchless transactions by way of Automated Teller Machines (ATMs), Self service Kiosks, Business Correspondents models, mobile banking and internet banking. These are measured per thousand square kilometer, thereby measuring the penetration of all services mentioned. Thus, a range of indicators has been used to measure the inclusiveness of a financial system however these indicators when used individually fail to adequately provide a comprehensive picture of financial inclusion in an economy.

Thus, in this paper, a comprehensive measure called Financial Inclusion Index (FII) is used to evaluate the extent of financial inclusion in the study area. To incorporate various dimensions of financial inclusion such as penetration of banking products and services, availability and usage of financial services in one single number, Index on Financial Inclusion (IFI) was developed (Sarma, 2012). This measure is extremely useful in comparing the level of financial inclusion across economies and can be used to examine the impact of policy initiatives on financial inclusion in a country.

Researches pertain to financial inclusion are mostly conducted in global level and national level with a standard designed by expertise of financial system from giant groups such as World Bank Group and Alliance for Financial Inclusion (AFI) (Leeladhar, 2006). Whereas the developing nations like India consists of heterogeneous topography by 
means of income and standard of living among the people, which has a high level of inequality on income where a standard policy of financial inclusion cannot be enacted throughout the nation. Consequently, a tailored model to a particular region is essential to appraise the status of that region and find out the reasons for financial exclusion.

This study identified the necessity of tailored model as the research gap which is not found in the previous studies. As this study is conducted only in the economically most backward districts of Tamil Nadu, the scope can further be extended to conduct the study in other states, between different states and nations.

\section{Core Objective of the Study}

From the light of research problem, literature review and research gap, the core objective of this study is to identify the extent of financial inclusion through a customized index.

\section{Research Methods}

\subsection{Population of the study}

According to Census report 2011 furnished by the Ministry of Rural Development, the Government of India, Tamil Nadu, consists of four economically most backward districts such as Cuddalore, Nagapattinam, Tiruvannamalai and Villupuram. The individual and overall population of the study area is tabulated in Table 1.

Table 1. Population of the study

\begin{tabular}{|l|c|}
\hline District & Population \\
\hline Cuddalore & $26,05,914$ \\
\hline Nagapattinam & $16,16,450$ \\
\hline Tiruvannamalai & $24,64,875$ \\
\hline Villupuram & $34,58,873$ \\
\hline Total Population & $1,01,46,112$ \\
\hline
\end{tabular}

Source: Census report (2011), The Ministry of Rural Development, The Government of India.

\subsection{Sample size determination}

The sample size for the abovementioned population is determined as 384 , which is derived using the formula of Krejcie \& Morgan (1970). The formula is:

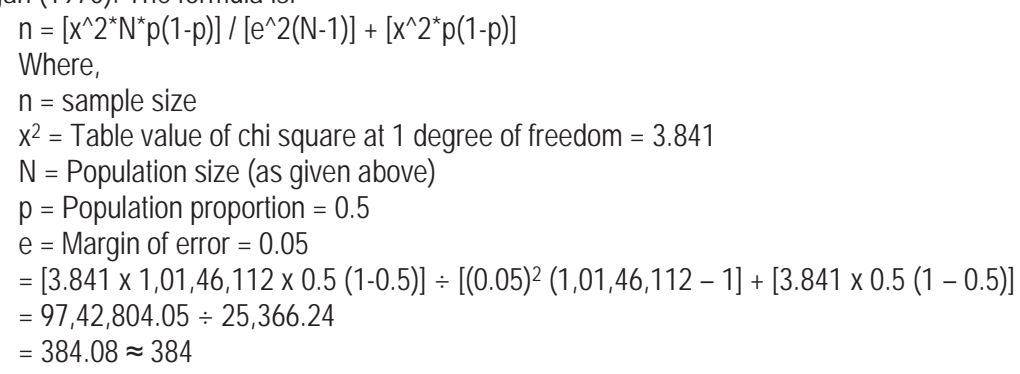

\subsection{Sampling method}

Under probability sampling, optimum allocation stratified random sampling method is used for this study, as it consists of four districts (strata) and the sample size is proportioned according to the corresponding stratum of the population. The strata being allocated is tabulated in Table 2 . 
Table 2. Allocation of sample based on stratum of population

\begin{tabular}{|l|c|c|}
\hline District & Population & Sample \\
\hline Cuddalore & $26,05,914$ & 99 \\
\hline Nagapattinam & $16,16,450$ & 61 \\
\hline Tiruvannamalai & $24,64,875$ & 93 \\
\hline Villupuram & $34,58,873$ & 131 \\
\hline Total & $\mathbf{1 , 0 1 , 4 6 , 1 1 2}$ & $\mathbf{3 8 4}$ \\
\hline
\end{tabular}

Source: Computed by researchers

The sample allocated in Table 2 is followed to collect the data from anonymous respondents for which, 500 questionnaires were distributed in the study area and 419 were returned back, out of which, 35 questionnaires were found incomplete and rejected. The remaining 384 samples were taken into account for the study.

\subsection{Data collection method}

\subsubsection{Primary data collection}

Primary data were collected on the basis of Global Findex questionnaire (2014), World Bank group, which is modified according to the region and the objective.

\subsubsection{Secondary data collection}

Secondary data were collected from World Bank Group report, Government of India report, articles, books and e-sources.

\subsection{Research design}

Descriptive survey is the suitable research method for this study because it discloses the characteristics of the respondents with reference to financial inclusion.

\subsection{Variables of this study}

\subsubsection{Demographic Profile}

Demographic profile of respondents consists of gender, age, income, education level, employment status, source of income and household composition (Alliance for Financial Inclusion, 2010).

\subsubsection{Financial inclusion index indicators}

To find out the extent of financial inclusion in the study area, three dimensions are used in this study such as access, availability and usage of financial system. The parameters to the said dimensions consist of both primary and secondary datasets collected by the researcher. Financial inclusion index indicators are tabulated in Table 3.

Table 3. Financial inclusion index indicators

\begin{tabular}{|l|l|l|l|}
\hline Dimension & Significance & Parameters & Description \\
\hline Access & $\begin{array}{l}\text { Number of bank accounts in the } \\
\text { study area. }\end{array}$ & Opening operative bank account \\
\hline Availability & $\begin{array}{l}\text { Number of access points in the } \\
\text { study area. }\end{array}$ & $\begin{array}{l}\text { Stepping stone for financial inclusion. Opening a bank } \\
\text { account to operate financial transactions. }\end{array}$ \\
\hline Usage & $\begin{array}{l}\text { Accounts hold by the respondents. } \\
\text { - Business Correspondents }\end{array}$ & $\begin{array}{l}\text { - Savings account } \\
\text { - Deposits account } \\
\text { - Loan account } \\
\text { - Credit account }\end{array}$ & $\begin{array}{l}\text { Supply side indicators. Information gathered from financial } \\
\text { institutions in person or website, based on the availability. }\end{array}$ \\
\hline
\end{tabular}

Source: Constructed by researchers 
In Table 3, dimension of availability consists of three parameters which are secondary data for this study. These dataset are collected from the Business Correspondents and websites of banks.

\subsection{Financial Inclusion Index (FII)}

The index in this study consists of two dimensions with seven parameters. It contains different unit of measurement and the result to be executed from each parameter of this study will not be found reliable. Hence the parameters are individually normalized using the formula given below:

Xi (Normalized) $=X i-X(\min ) / X(\max )-X(\min )$

Where,

$X i=$ actual value of ith dimension

$X(\min )=$ minimum value of ith dimension

$X(\max )=$ maximum value of ith dimension

To compute the normalization, each dimension parameters in the dimension were allocated weight. For access dimension, the weight is assigned as $1 / 3^{\text {rd }}$ for each of the three parameters. In case of usage dimension, $1 / 4^{\text {th }}$ weight is assigned to each of the four parameters. After the weights are assigned and the data are normalized, the final formula for financial inclusion is worked out as below. For the upcoming formula, the weight for each dimension is assigned as follows:

Access $=1.0$ weight

Availability $=0.5$ weight

Usage $=0.5$ weight

In the above weights, availability and usage dimensions are given 0.5 because there are factors like internet banking and mobile banking which are not considered as parameters for this study due to unavailability of reliable information, time and cost factor. These weights are assigned to the formula for financial inclusion index given below:

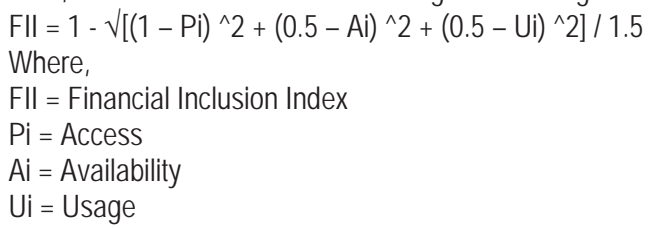

The result executed by the above formula falls between zero (0) and one (1), where zero represents absolute financial exclusion and one represents absolute financial inclusion of the people in an economy where the study is being conducted (Sarma \& Pais, 2008). CRISIL Inclusix (2013), an index for financial inclusion developed by Credit Rating Information Services of India Limited (CRISIL) with the support of Ministry of Finance, India, has assigned level of financial inclusion based on four levels of scores. It is being modified for this study and tabulated in Table 4.

Table 4. Financial inclusion index scores

\begin{tabular}{|l|l|}
\hline Index Score & Financial inclusion level \\
\hline Greater than 0.55 & High \\
\hline Between 0.40 and 0.55 & Above average \\
\hline Between 0.25 and 0.40 & Below average \\
\hline Less than 0.25 & Low \\
\hline
\end{tabular}

Source: Modified from CRISIL Inclusix

The scores mentioned in Table 4 portrays a clear description of scores from which the user can effortlessly rank a particular district in a state and can able to identify the minor difference in the results of the region being studied using these scores.

\subsection{Reason to choose Financial Inclusion Index (FII) as the methodology}

The key reason to use Fll as the methodology in this study is because, it addresses core necessities such as opening bank account, savings, borrowings, remittance and payment and insurance to financially include the excluded, which can 
measure and analyze the progress of financial inclusion of particular district in a state and the whole state and the nation as well. As the result, the financial status of a particular area can be identified where this index is applied.

\section{Results and Discussion}

\subsection{Result from demographic profile of the respondents}

Literature review related to financial inclusion had realized that financial exclusion results to social exclusion, which enhances poverty and unemployment. Researches were carried out to identify the people affected by financial exclusion particularly in developing nations and found that it occurs among low-income groups, the aged, ethnic minorities, refugees and immigrants (Connoly \& Hajaj, 2001). It also affects the people living in remote rural villages where they do not even fulfill their basic needs to lead daily life. These reviews are found appropriate to this study, which consists of wide remote and rural regions as study area, consequently the demographic profile of the respondents are collected in random, tabulated in Table 5.

Table 5. Demographic profile of the respondents

\begin{tabular}{|c|c|c|c|}
\hline \multicolumn{2}{|r|}{ Demographic profile } & Frequency & Percentage (\%) \\
\hline \multirow{2}{*}{ Gender } & Male & 261 & 68.0 \\
\hline & Female & 123 & 32.0 \\
\hline \multicolumn{2}{|l|}{ Gender total } & 384 & 100.0 \\
\hline \multirow{5}{*}{ Age } & $15-25$ & 79 & 20.6 \\
\hline & $25-35$ & 133 & 34.6 \\
\hline & $35-45$ & 96 & 25.0 \\
\hline & $45-55$ & 55 & 14.3 \\
\hline & 55 and above & 21 & 5.5 \\
\hline \multicolumn{2}{|l|}{ Age total } & 384 & 100.0 \\
\hline \multirow{5}{*}{ Income } & Less than Rs.5,000 & 98 & 25.5 \\
\hline & Rs. 5,000 to Rs. 10,000 & 216 & 56.3 \\
\hline & Rs. 10,000 to Rs. 20,000 & 49 & 12.8 \\
\hline & Rs. 20,000 to Rs. 30,000 & 12 & 3.1 \\
\hline & Rs.30,000 and above & 9 & 2.3 \\
\hline \multicolumn{2}{|l|}{ Income total } & 384 & 100.0 \\
\hline \multirow{3}{*}{ Educational qualification } & Post Graduation and/ or Professional qualification & 48 & 13.8 \\
\hline & Under Graduation and/ or Diploma & 91 & 26.1 \\
\hline & Schooling & 210 & 60.2 \\
\hline \multicolumn{2}{|l|}{ Educational qualification total } & 349 & 100.0 \\
\hline \multirow{3}{*}{ Source of income } & Employment & 234 & 69.4 \\
\hline & Business & 85 & 25.2 \\
\hline & Non - Working Income (Rental Income, Interest) & 18 & 5.3 \\
\hline \multicolumn{2}{|l|}{ Income source total } & 337 & 100.0 \\
\hline \multirow{5}{*}{ Number of family members } & One & 12 & 3.1 \\
\hline & Two & 106 & 27.6 \\
\hline & Three & 167 & 43.5 \\
\hline & Four & 53 & 13.8 \\
\hline & More than Four & 46 & 12.0 \\
\hline \multicolumn{2}{|c|}{ Number of family members total } & 384 & 100.0 \\
\hline
\end{tabular}

Source: Primary data

Table 5 depicts the demographic profile of the respondents from whom the data was collected. It was found from the above table that the respondents of $68 \%$ were male and $32 \%$ were female. Many respondents fall in the age group of 25 to 35 years with $34.6 \%$. With regards to income, $56.3 \%$ respondents fall between the income level of Rs.5,000 and Rs. 10,000 , whereas $60.2 \%$ were qualified up to schooling. In case of employment, $69.4 \%$ were employed with salary 
and/ or wages and there were $43.5 \%$ of respondents with three family members. It was further found that there were 349 respondents responded to educational qualification and the remaining 35 were found to be uneducated. In case of source of income, 47 respondents were found unresponsive and the most reason is lack of earnings and unemployment.

\subsection{Results pertain to financial inclusion index}

This study was conducted among economically most backward districts of Tamil Nadu, India. Table 6 depicts the availability dimension that consists of three parameters such as number of Automated Teller Machines (ATMs), number of bank branches and number of Business Correspondents (BCs) in the study area.

Table 6. Dimension of Availability

\begin{tabular}{|l|c|c|c|}
\hline \multirow{2}{*}{ Districts } & \multicolumn{3}{|c|}{ Parameters of availability dimension } \\
\cline { 2 - 4 } & Number of ATMs & Number of Bank branches & Number of BCs \\
\hline Cuddalore & 71 & 225 & 416 \\
\hline Nagapattinam & 48 & 159 & 172 \\
\hline Thiruvannamalai & 21 & 170 & 545 \\
\hline Villupuram & 54 & 239 & 970 \\
\hline Total of districts & 194 & 793 & 2,108 \\
\hline Total of Tamil Nadu state & 18,320 & 8,841 & 7,748 \\
\hline Percentage of the above districts with proportion to Tamil Nadu & $1.1 \%$ & $9.0 \%$ & $27.1 \%$ \\
\hline
\end{tabular}

Source: www.rbi.org.in; State Level Bankers' Committee, Tamil Nadu

It was found from Table 6 that $1.1 \%$ of ATMs in Tamil Nadu are installed in the aforesaid districts. But the bank branches were found to be $9 \%$ hence it was clear that all the bank branches do not install ATMs and the people apart from the users of ATM should walk into the bank to withdraw money. It was said by the respondents that they need to travel long distance to reach the bank branch to deposit the money. BCs stated that banks regulate them to settle the transacted accounts daily for which they should reach the branch from their village by travelling a long distance.

The information in Table 6 and the data collected pertain to dimensions of access and usage was analyzed using formula (3). The result derived is tabulated in Table 7.

Table 7. Financial inclusion index

\begin{tabular}{|c|l|c|l|c|}
\hline S. No. & Districts & Score & Level & Rank \\
\hline 1 & Cuddalore & 0.349 & Below average & 2 \\
\hline 2 & Nagapattinam & 0.320 & Below average & 3 \\
\hline 3 & Thiruvannamalai & 0.211 & Low & 4 \\
\hline 4 & Villupuram & 0.481 & Above average & 1 \\
\hline
\end{tabular}

Source: Computed by researchers

Table 7 depicts the financial inclusion result of each district. This result reveals the level of financial inclusion where Villupuram district has scored 0.481 and secured the level of above average with first rank, since it has higher score than the other district. Cuddalore and Nagapattinam districts have scored 0.349 and 0.320 respectively, cited as below average. The results do not disclose any high financial inclusion. The reason was inequality of income which generates a handful of money for an individual to meet daily basic needs. Eventually the money cannot be saved or invested and creates an impossibility to meet emergency expense. Lack of savings and investments leads to less flow of money in a particular region, where the bank cannot open its branches as it need to spend administrative and operating costs such as salary to employees, building rent and electricity charges.

\section{Conclusion}

Financial inclusion is the gateway to financial access of products and services being offered by the formal financial 
institutions such as banks, post offices and insurance companies at affordable cost. This policy is designed for needy people to pull away them from economic evils such as poverty, unemployment and from unscrupulous lenders. This study was undergone to find out the status of financial inclusion in the study area, which resulted in lack of high financial inclusion. The reasons for financial exclusion are lack of income due to unemployment, financial illiteracy, complexity in documentation for account opening and lack of help desk to guide the people with doubt on banking transaction. To enhance financial inclusion in the nation, it is essential for the concerned authorities such as the Government of India and the Reserve Bank of India to scrutinize the reach of financial inclusion and it is the duty of the people to involve in the process of financial inclusion which leads the financially excluded to access financial products and services at affordable cost, time and distance.

\section{References}

AFI (Alliance for Financial Inclusion). (2010). Financial inclusion measurement for regulators: Survey Design and Implementation. Policy paper, Date Working Group, AFI, Bangkok.

Anderloni, L., \& Carluccio, E. M. (2007). Access to bank accounts and payment services. In New Frontiers in Banking Services (pp. 5105). Springer Berlin Heidelberg.

Beck, T., Demirgüç-Kunt, A., \& Honohan, P. (2009). Access to financial services: Measurement, impact, and policies. The World Bank Research Observer.

Beck, T., Demirguc-Kunt, A., \& Peria, M. S. M. (2007). Reaching out: Access to and use of banking services across countries. Journal of Financial Economics, 85(1), 234-266.

Claessens, S. (2006). Access to financial services: A review of the issues and public policy objectives. The World Bank Research Observer, 21(2), 207-240.

Connolly, C., \& Hajaj, K. (2001). Financial services and social exclusion. Financial Services, Consumer Policy Centre, University of New South Wales.

Conroy, J. D. (2008). Financial inclusion: A new microfinance initiative for APEC. Brisbane, Australia: The Foundation for Cooperation.

Demirgüç-Kunt, A., \& Klapper, L. F. (2012). Measuring financial inclusion: The global findex database. World Bank Policy Research Working Paper, (6025).

Hanning, A. \& Jansen, S. (2010) Financial inclusion and financial stability: current policy issues. ADBI working paper series, No. 25 (9), Asian Development Bank Institute.

Honohan, P. (2008). Cross-country variation in household access to financial services. Journal of Banking \& Finance, 32(11), 24932500 .

Krejcie, R. V., \& Morgan, D. W. (1970). Determining sample size for research activities. Educ Psychol Meas.

Leeladhar, V. (2006). Taking banking services to the common man-financial inclusion. Reserve Bank of India Bulletin, 60(1), 73-77.

Okpara, G. C. (2011). Financial Inclusion and Financial Stability: A Toda-Yamamoto Causality Approach. Social Sciences (Jamelss), 1(1), 86-100.

Peachy, S., \& Roe, A. (2006). Access to finance: What does it mean and how do savings banks foster access. WSBI, World Savings Banks Institute.

Sarma, M. (2008). Index of financial inclusion. Indian Council for Research on International Economics Relations.

Sarma, M. (2012). Index of Financial Inclusion - A measure of financial sector inclusiveness (No. 1207). Hochschule fuer Technik und Wirtschaft, Berlin.

Sarma, M., \& Pais, J. (2008). Financial inclusion and development: A cross country analysis. Indian Council for Research on International Economic Relations, 1-28. 